\title{
De quem são as responsabilidades: dos médicos, dos residentes, dos professores, dos dirigentes...
}

preocupação com a valorização de nossa oftalmologia precisa e deve ser constante. Afinal,
dizia sempre minha avó: "Quem gosta de Você é só Você mesmo."
No meu entender a valorização de nossa profissão inicia-se com o nosso posicionamento
com os pacientes.

Somos profissionais e, portanto, temos a obrigação de nos atualizarmos constantemente para sermos considerados excelentes prestadores de serviços e podermos exigir também, que nossos honorários sejam atualizados adequadamente. A Medicina é um sacerdócio quando nos referimos à dedicação, mas não podemos deixar que este fato seja utilizado para isentarmos nossos pacientes da cobrança dos honorários. Isto precisa ser uma decisão pessoal do médico.

Também é preciso lembrar que todo relacionamento está fundamentado no respeito mútuo: precisamos ouvir e participar da queixa, dor e sofrimento de nossos pacientes, mas exigir que o nosso profissionalismo seja considerado e respeitado.

Somos oftalmologistas e diuturnamente buscamos o aperfeiçoamento das imagens: queremos que todos enxerguem perfeitamente. As equipes que nos cercam diariamente em nosso trabalho devem ser outra preocupação nossa, pois afinal representam a nossa imagem junto aos nossos pacientes. A orientação, treinamento e aperfeiçoamento constantes ajudarão muito na nossa valorização como profissionais.

Continuando nesta reflexão sobre a valorização da oftalmologia, não podemos esquecer-nos de relacioná-la às varias estratégias que hoje utilizamos dentro do contexto da administração.

Precisamos estar sempre interrogando quais são os limites mínimos com os quais podemos associar a ética e o respeito e assim trilharmos o caminho da socialização da medicina com qualidade.

Chega o momento do nosso relacionamento com as empresas prestadoras de serviços médicos, comumente denominadas convênios.

Talvez seja esta a hora quando o nosso empenho na busca da valorização da oftalmologia atinge o seu ápice: é preciso que a ética, a honestidade e, fundamentalmente, o respeito ao nosso paciente sejam mais considerados.

Somos solicitados pelas empresas prestadoras de serviços médicos a atendermos um maior número de pacientes em um menor tempo a fim de podermos nos colocar dentro de um mercado de trabalho que não enaltece a qualificação médica, mas sim propicia desvios da ética como justificativa da necessidade de sobrevivência.

Precisamos, nesta época de globalização, refletir para onde estamos caminhando, pois não são só as empresas prestadoras de serviços médicos mas também aquelas diretamente ligadas às atividades oftalmológicas, que justificadas pela necessidade constante de atualização (Parabéns!!!), cerceiam os médicos com mudanças constantes nos modelos dos seus equipamentos, deixando aqueles que por eles mesmos eram considerados os melhores sem nenhuma possibilidade de troca de peças ou mesmo de manutenção. Na maioria das vezes, somos informados que só servem para os depósitos dos "ferros velhos". 
A busca da valorização é um caminho cheio de obstáculos!!!.....

E as Entidades Representativas da Classe? E as Universidades? E o Governo? O que podem fazer para a Valorização da Oftalmologia?

Para justificarem suas obrigações com a nossa população devem e precisam fazer MUITO.

Tenho a convicção que somente conseguiremos a Valorização e, consequentemente, o retorno do respeito do paciente para com o médico, através de nossa União.

- A UNIÃO FAZ A FORÇA -

- A FORÇA TRAZ O RESPEITO -

- COM RESPEITO SE CONSEGUE A VALORIZAÇÃO -

Prof. Dr. José Ricardo C. L.Rehder Chefe e Titular da Disciplina de Oftalmologia Faculdade de Medicina do ABC 